\title{
The Investigation of the Online Customer Experience and Perceived Risk on Purchase Intention in China
}

\author{
Hleb Dabrynin \\ Huazhong University of Science and Technology \\ Jing Zhang \\ Huazhong University of Science and Technology
}

The development of the e-commerce all over the world makes purchase intention an important research area in marketing. This study furthers an understanding of how online customer experience and perceived risk effects purchase intention in China. To investigate the hypotheses of the research, totally 303 users participated in this survey. The participants answered the questionnaire based on their experience in Jing Dong (JD), the largest e-commerce site in China. The results provide valuable strategies and contribute to the literature on purchase intention in China.

\section{INTRODUCTION}

Nowadays, online shopping has become an essential instrument for communication between businesses and consumers worldwide. The development of online shopping in the world has attracted more and more consumers purchasing online. Online shopping has become a popular shopping style (Bourlakis et al., 2008).

According to Internet World Stats (2019) report, there were 4.2 billion internet users in 2018, and the majority of them were from Asian countries. The Asian region has 49 percent of the total number of Internet users. China ranks first among Asian countries in the number of Internet users. National Bureau of Statistics of China reported that the national online retail sales totalled $\$ 1.33$ trillion (just over 9.00 trillion yuan) in 2018 and increased by 23.9 percent as compared with 2017 . In the structure of the total retail sales of physical consumer goods, online sales reached up to 18.4 percent (National Bureau of Statistics of China, 2019). Thus, online shopping has become a vital concern for traditional retail stores in certain product areas.

In spite of the growth of online shopping and e-commerce infrastructure, this development has created new problems and challenges in the online market. In an online environment, online shopping is regarded as a risky activity (Almousa, 2011). Purchase intention is affected by the perceived risk, which can be a reason for customers not to purchase online and it is essential that a business take into account the perceived risk (Kim et al., 2008). Scientists have proved that perceived risk plays a vital role while doing online shopping, because in such circumstances consumers feel unsafe about their purchase decisions (Bhatnagar \& Ghose, 2004; Jiuan Tan, 1999). According to Forsythe and Shi (2003), the 
analysis of perceived risk in online shopping is a necessary step to understand the nature and types of perceived risk, that influence a consumer purchase intention.

Customer experience is often considered one of the most crucial issues for businesses (Verhoef et al. 2009). Furthermore, online customer experience affects the perceptions customers and their positive intentions to purchase online (Zhou et al., 2007; Kuhlmeier \& Knight, 2005). Thus, it's important to investigate customers' online experiences and their role in purchase intentions.

There is a need to understand better and predict consumers' online purchase intentions to consider significant implications for marketers to formulate innovative business strategies. There have been intensive studies of online purchase intention in recent years. Most of them have tried to identify the factors, related to online purchase intentions (Khaniwale, 2015; Akbariyeh et al., 2015; Gerber et al., 2014). However, in China, only a few studies have been undertaken on the variables associated with online purchase intentions (Zhang et al., 2012; Gan \& Wang, 2017). Therefore, this study contributes to the literature by comprehensively exploring the main factors influencing purchase intentions during online shopping. Finally, the purpose of this study is to: (1) analyze online customer experiences, and three dimensions of perceived risk associated with purchase intentions online, (2) examine the influence of online customer experiences on perceived risks. This research creates a conceptual framework that demonstrates the relationship between the variables. Based on the research data, perceived risk dimensions, which have a significant impact on purchase intentions, are proposed. This study used a partial least squares (PLS) method to analyze data from a sample of 303 users who made purchases with Jing Dong. Although this study has some limitations since only the data from the e-commerce site Jing Dong has been used, the results have important practical implications not only for e-commerce but decision makers as well. From a theoretical point of view, the results of this study contribute to our understanding of the significant effect of online customer experiences, perceived risks on the purchase intentions.

\section{THEORETICAL FRAMEWORK AND HYPOTHESES}

\section{The Concept of Consumer Purchase Intention}

At present consumer purchase intention is one of the most popular research areas in marketing. Managers usually use consumer purchase intention to predict the sales of existing or new products. Purchase intention data can help marketers to make decisions and develop promotional strategies. Close and Kukar-Kinney (2010) state that online purchase intention emerged from purchase intention. Meskaran et al. (2013) argue that online purchase intention as the customers' preparedness to purchase in the online platform. Purchase intention is the components of consumer cognitive behavior, which describes a specific intention to buy a specific product (Ling et al., 2010). According to Pavlou (2003), online purchase intention takes place when a customer is willing and intends to become involved in an online transaction. Consumer purchase intention on the Internet defines the strength to conduct purchasing behavior online (Salisbury et al., 2001). Purchase intention is usually connected with consumer behavior, perceptions, and attitudes and can be a successful instrument to predict the buying process (Akbariyeh et al., 2015). The prediction of the buying process depends on the influencing factors that make this process complicated in different situations.

\section{The Concept of Perceived Risk}

Perceived risk is a much discussed topic in literature and the research focuses on its long-term influence on businesses. Perceived risk can be measured in terms of the magnitude of the negative consequences and the estimated probability of these consequences to follow a specific action or behavior. If the consequences of the action or behavior are serious and likely to occur, people tend to avoid that behavior (Peter \& Tarpey, 1975). Perceived risk in online shopping is defined as the consumer's cognition about possible uncertain negative outcomes resulting from an online purchase (Kim et al., 2008). Ashoer and Said (2016) affirm that a higher risk forces the customers to obtain more information, so it will greatly influence the customer's purchase intention, and in many cases, the customer refuses to 
purchase this product. Kim et al. (2008) argue that perceived risks could be a reason for customers not to purchase online and that is why it is crucial for e-commerce companies to consider these risks. Thus, perceived risk has become one of the most important and strong concepts in explaining customer's behavior.

The six components of perceived risk associated with shopping are identified as following: physical, social, product, convenience, financial, and psychological risks (Peter \& Tarpey, 1975). According to Bhatnagar et al. (2000) on the Internet, there are three main types of risk: financial risk, product risk, and information risk (security and privacy). Durmus et al. (2017) state that product and financial risks exert strong and negative influence on consumers' purchase intentions as compared with other types of risk. Besides, another study proves that privacy risk becomes a serious problem among online consumers (Drennan et al., 2006). This research focuses on product risk, financial risk, and privacy risk and their effect on purchase intentions.

Scientists describe product risk as the probability of failing to meet the performance requirements (Peter \& Tarpey, 1975). Product risk is viewed as the most significant reason not to purchase online. For example, product risk can easily decrease the consumer's confidence and intention during online shopping. When the order and delivered product do not match with consumer expectations, the consumer will consider the product incapable of satisfying their needs (Kamalul Affirin et al., 2018). Product risk is especially highly expected when a consumer buys some product online and is unable to examine it physically and test its characteristics online (Alreck \& Settle, 2002). Bhatnagar et al. (2000) indicate that risks related to product unreliability are likely to have a negative impact on online purchase intention - at least for some products. Bhatnagar and Ghose (2004) state that product risk influences shoppers' online purchase intentions significantly. The above discussion puts forward the following hypothesis:

\section{H1: Product risk is negatively related to the customer online purchase intention.}

Financial risk is considered as the probability of losing money from a purchase (Horton, 1984; Sweeney et al., 1999). There are various reasons why online customers can suffer a financial loss during shopping online. Firstly, it is difficult for customers to determine the product price that they purchase from an online retailer and compare it with other suppliers. Secondly, financial losses can arise from credit card fraud, which is a common financial problem among online shoppers. Besides, buyers do not consider buying products online, which includes additional costs, such as shipping (Dai et al., 2014). In general, consumers regard financial risk as a negative factor associated with online shopping, which could forecast consumers' online intentions. The high level of financial risk decreases the purchase frequency and consumer activity in the online platforms (Forsythe et al., 2006). Thus, based on the findings of several studies, $\mathrm{H} 2$ is proposed:

\section{H2: Financial risk has a negative effect on online purchase intention.}

Garbarino and Strahilevitz (2004) recognize privacy risk as the probability of personal information being stolen during online transactions. Privacy concern is one of the basic barriers for consumers to be involved in electronic commerce (e-commerce) transactions, which require them to issue personal information: date of birth, identification number, telephone number, and credit card information. Thus, privacy concern is regarded as the main threat to e-commerce and the digital economy (Gurung \& Raja, 2016). Mekovec and Hutinski (2012) identify the following reasons to investigate users' privacy risk: (1) the ease of collecting and searching information about anybody, due to technology impact on privacy, (2) every individuals' activity in the digital world exists in persistence, (3) the lack of privacy protection and great possibility of users' privacy invasion. Nowadays, consumers have problems concerning the flow of personal information between consumers and online platforms, and how their personal information is supervised by online shopping platforms (Hong \& Thong, 2013). Chapell (2005) evaluates online behavior in the USA and discovers that more than 69 percent of consumers restrict themselves 
from online shopping because of privacy risk related to personal information. Based on this discussion, $\mathrm{H} 3$ is sugested

\section{H3: Privacy risk has a negative impact on shoppers' purchase intention.}

\section{The Concept of Online Customer Experience}

A lot of studies emphasize the significant role of the customer experience in online shopping. Johnston and Kong (2011) identify the importance of online customer experience for companies because it affects customer satisfaction. Grewal et al. (2009) state that to compete effectively in today's competitive and dynamic environment, retailers must focus on online customer experience. Moreover, customer experience is complex and contains cognitive, social, affective and physical elements (Verhoef et al., 2009). According to Michaud-Trevinal and Stender (2012), experience means testing, trying and referring to experiments and knowledge that are based on sensory experience and opposite to pure and a priori knowledge. Experience differs from behavior, which is a visible part of the experience (what is seen from the outside) and differs from the situation itself. A variety of word combinations for online experience exist in the literature, such as "online customer experience", (Rose et al., 2012), "website experience" (Kim et al., 2009), and "online purchase experience" (Holloway et al., 2005). Rose et al. (2012) define the online customer experience as a psychological state manifested as a subjective response to the website. The customer is involved in the cognitive and effective process of incoming information from the online platform, and the outcome creates an impression in memory.

As to experience, scientists have shown that it affects consumers' perceptions and intentions positively to purchase online (Zhou et al., 2007; Kuhlmeier \& Knight, 2005). Individually, higher experience leads to increased satisfaction with online shopping and increased numbers of completed purchases. Shim and Drake (1990) argue that customers with a strong desire to purchase goods online have a prior online experience that helps them to decrease uncertainties. Thus, customers will only buy a product online if they have experience to purchase it.

Liang and Huang (1998) have found that customers with great experience are likely to continue shopping. They also state that customers who have prior online purchase experience will purchase through online than those who lack such experience. In addition, Seckler (2000) proves that a first-time small purchase can give customer experience with the online platform, later they develop confidence and ability to be more ambitious during online shopping.

Moreover, Festervand et al. (1986) investigate that previous experience through the online channel is not positively connected with perceived risks identified with future shopping in that channel. His study claims that online experience causes a reduction in perceived risks during an online purchase.

Kuhlmeier and Knight (2005) and Doolin et al. (2005) argue that risks associated with online shopping decrease as online customer experiences increase. However, many consumers are still extremely concerned about risk perceptions related to online shopping (Gerber et al., 2014). Thus, it is essential to examine the impact of experience on perceived risk that affects online shopping intention. This leads to the following hypotheses:

H4: Online customer experience is negatively related to product risk.

H5: Online customer experience is negatively related to financial risk.

H6: Online customer experience has a negative effect on privacy risk.

H7: Online customer experience positively influences online purchase intention.

According to Miles and Huberman (1994), a conceptual framework explains the crucial issues graphically or narratively and the main factors, constructs or variables, and the presumed interactions 
between them. The conceptual framework presented in this paper includes some variables which aim to determine the connection and effects of these attitudes on online purchase intention. In this study, the conceptional framework was developed to analyze the effect of the online customer experience on online purchase intention both directly and indirectly through the risk perceptions. Each type of risk (product, privacy and financial) influences purchase intention individually.

\section{FIGURE 1 \\ CONCEPTUAL FRAMEWORK}

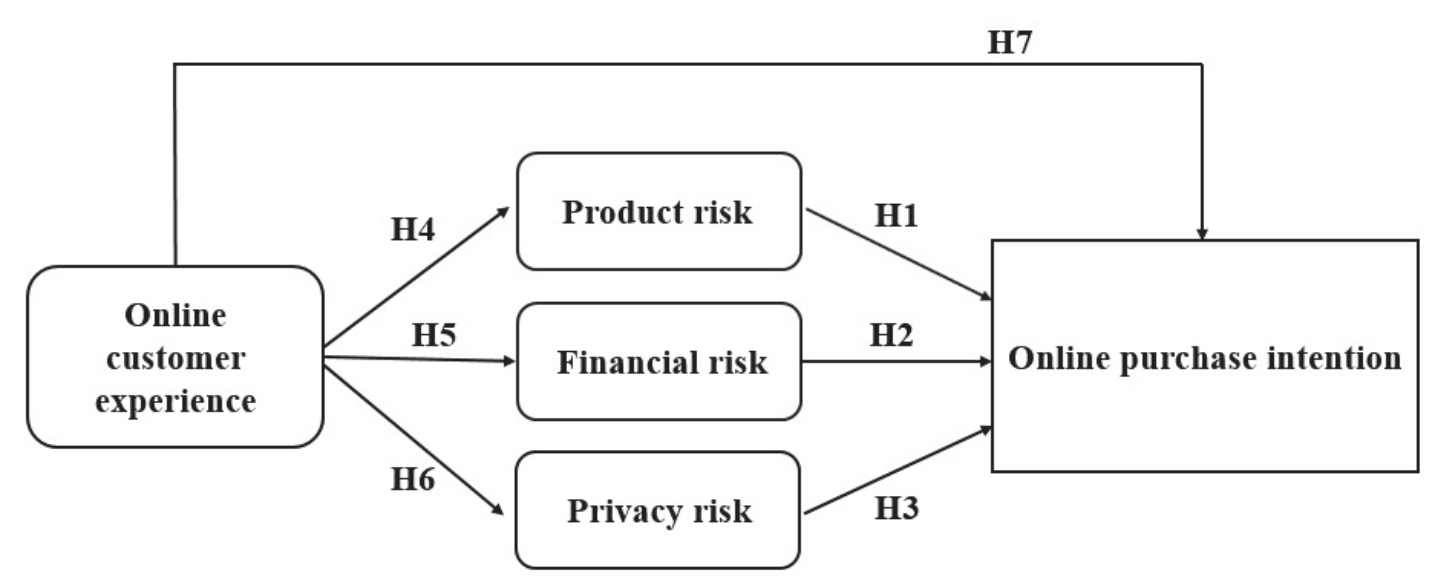

The proposed research model (see Figure 1) has the following five constructs: online customer experience, product risk, privacy risk, financial risk, and online purchase intention. The concept of online customer experience was used from Rose et al. (2012). The concept of product risk was adopted from Peter and Tarpey (1975), and privacy risk was taken from Garbarino and Strahilevitz (2004). The idea of financial risk was derived from Horton (1984) and Sweeney et al. (1999). Based on Pavlov (2003), the concept of online purchase intention was successfully adopted.

\section{RESEARCH METHODOLOGY}

\section{Questionnaire Design}

The questionnaire was conducted to test the research model and hypotheses based on survey data collected from Jing Dong, one of the largest e-commerce sites in China. According to the conceptual framework, the questionnaire was divided into two parts. The first part included demographic variables (ethnicity, age, and education), which were measured by scale. The second part included measures of the variables, which were identified in the literature review section: online customer experience, three types of risk and online purchase intention. The questionnaire has a five-point Likert-type scale system, one means "strongly disagrees" and five means "strongly agree." The measured variables of the survey questionnaire in this research were adopted from different sources of literature. 
TABLE 1

MEASURED VARIABLES, QUESTION ITEMS AND SOURCE

\begin{tabular}{lcl}
\hline Measured variables & Question items & Source \\
\hline $\begin{array}{l}\text { Online customer } \\
\text { experience }\end{array}$ & 3 & Bruseke (2016) \\
Product risk & 5 & Alreck and Settle (2002) \\
Privacy risk & 4 & Garbarino and Strahilevitz (2004) \\
Financial risk & 5 & Zhang et al. (2012) \\
Online purchase & 5 & Pavlov (2003) \\
intention & 22 & \\
Total: & & \\
\hline
\end{tabular}

\section{Research Content}

JD is China's largest e-commerce website and one of the world's top 10 most visited sites. JD was launched in January 1998. In 2014 JD.com was listed on New York's NASDAQ stock exchange. The company sells and distributes to consumers different kinds of products: electronics and software, clothes, health care and pharmaceutical products, sports equipment, food. JD cooperates with manufacturers and distribution companies across China and connects with consumers through the website, www.jd.com. The company has all available products for both men and women (Reuters, 2019). The company competes with huge e-commerce retailers like Alibaba Group, Amazon China, Walmart. The questionnaire was targeted only at those with previous experience in shopping on JD.com. The questionnaire forms with obvious errors were deleted from the survey.

\section{Procedures}

\section{Pretest}

Before the actual survey was tested, a pre-test, using a convenience sample of 30 students from Huazhong University of Science and Technology had been conducted to examine the legibility and accuracy of the items in the questionnaire procedure. Pre-test also gave the evidence for the validity and reliability of the data survey. The pre-test was held in the School of Management by filling a questionnaire form. Participation in the study was entirely voluntary. All questions in the pre-test procedure were put in English. After the questionnaire was completed, every participant reported how much time was required to complete the survey. Generally 10 minutes was enough to finish the pre-test. At the end of the survey procedure, the questions were asked to understand respondents' feedback concerning the items of the questionnaire, the level of sufficiency and accuracy of the questionnaire. These recommendations were used in the modification of the survey items. For example, to measure participants' expenditure in JD.com, respondents were asked about the amount of money spent in JD online market during the past 12 months. The majority of respondents mentioned answer 4 (more than $500 \mathrm{RMB}$ ). Developing a more detailed measure scale was necessary. The measurement scale was modified by adding answer 4 (500-1000 RMB) and answer 5 (more than $1000 \mathrm{RMB}$ ). It would be sufficient to have five categories of answer for the final survey version. The final survey was adjusted and published based on the results of the pre-test and respondents' recommendations.

\section{Actual Survey}

The actual survey was developed to collect data for examining the research hypotheses. The questionnaire was targeted at participants who previously purchased online and were familiar with JD.com platform. Those people without shopping experience in JD.com were excluded from the survey. Respondents were assured of the confidentiality and voluntary aspects of participating in the survey. The survey was conducted in two ways. The first part included answering the questionnaire in various places 
(universities, public areas) where respondents could return their survey answers immediately. The second part was aimed at conducting an online survey. Many scholars have reported that using the online survey approach in the context of online shopping was the most efficient and acceptable data collection method (Chen \& Barnes, 2007; Chang \& Wang, 2011). The survey was published via social media and answers were collected with a response rate of about 85 percent. Some different methods were used for attracting respondents. The questionnaires were distributed among 366 participants, and 311 questionnaires were collected. Only eight sets of questionnaires were not completed by respondents. The reason can be explained by the unwillingness to participate in the research survey. The uncompleted questionnaires were eliminated from the actual survey to guarantee a high quality of data.

Descriptive statistics indicated that among the 303 respondents, $39.3 \%$ were females and $60.7 \%$ were males. The majority (74.2\%) were aged between 20 and 30 years old, $21.8 \%$ were above 30 years old and only $4 \%$ were below 20 years old. Table 2 presents the characteristics of the respondents that were used in the empirical analysis.

TABLE 2

DESCRIPTIVE STATISTICS OF SAMPLE DATA

\begin{tabular}{|c|c|c|c|}
\hline Characteristic & Variables & Frequency & Percent $(\%)$ \\
\hline \multicolumn{4}{|l|}{ Sex } \\
\hline & Male & 184 & 60.7 \\
\hline & Female & 119 & 39.3 \\
\hline \multicolumn{4}{|l|}{ Ethnicity } \\
\hline & African-American & 6 & 2 \\
\hline & Asian & 240 & 79.2 \\
\hline & Caucasian & 31 & 10.2 \\
\hline & Hispanic & 8 & 2.6 \\
\hline & Other & 18 & 5.9 \\
\hline \multicolumn{4}{|l|}{ Age (years) } \\
\hline & below 20 & 12 & 4 \\
\hline & $20-30$ & 225 & 74.2 \\
\hline & above 30 & 66 & 21.8 \\
\hline \multicolumn{4}{|c|}{ Educational level } \\
\hline & High school diploma or below & 16 & 5.3 \\
\hline & Bachelor's degree & 95 & 31.4 \\
\hline & Master's degree & 125 & 41.3 \\
\hline & Doctoral degree & 67 & 22.1 \\
\hline \multicolumn{4}{|l|}{ Occupation } \\
\hline & Student & 181 & 59.7 \\
\hline & Company employee & 105 & 34.7 \\
\hline & Self-employed & 13 & 4.3 \\
\hline & Unemployed & 4 & 1.3 \\
\hline \multicolumn{4}{|c|}{ Income (per month) } \\
\hline & under 1000 & 30 & 9.9 \\
\hline & $1001-3000$ & 69 & 22.8 \\
\hline & $3001-6000$ & 114 & 37.6 \\
\hline & more 6000 & 90 & 29.7 \\
\hline
\end{tabular}


According to the descriptive statistics respondents were divided into two major groups, those who were students $(59.7 \%)$, and those who worked in the companies $(34.7 \%)$, only $1.3 \%$ of respondents were unemployed. The majority of the respondents were Asian (79.2\%), Caucasian (10.2\%), Hispanic $(2.6 \%)$, African-American (2 \%). Furthermore, other ethnicities among respondents run up to $5.9 \%$. The education level was as follows: 5.3\% were from high school diploma or below; $31.4 \%$ hold bachelor's degree; $41.3 \%$ were masters, and $22.1 \%$ had a doctoral degree.

Table 3 illustrates the experience of the respondents in online shopping. The majority of respondents $(78.2 \%)$ considered themselves to be advanced online users. Descriptive statistics presented upperintermediate users as $17.8 \%$ and participants with less experience $(4 \%)$. Some of the respondents $(44.2 \%)$ reported that they were at the intermediate level of the online shopping experience, while the rest were at beginner $(31.4 \%)$ and expert $(24.4 \%)$ levels respectively.

\section{TABLE 3}

\section{RESPONDENTS' ONLINE EXPERIENCE CHARACTERISTICS}

\begin{tabular}{|c|c|c|c|}
\hline Measurement & Option & Frequency & Percent $(\%)$ \\
\hline \multicolumn{4}{|c|}{ Internet experience } \\
\hline & Less than one year & 12 & 4 \\
\hline & $1-5$ years & 54 & 17.8 \\
\hline & Six years or more & 237 & 78.2 \\
\hline \multicolumn{4}{|c|}{ Internet shopping duration } \\
\hline & Less than one year & 95 & 31.4 \\
\hline & $1-3$ years & 134 & 44.2 \\
\hline & Four years or more & 74 & 24.4 \\
\hline \multicolumn{4}{|c|}{ Online shopping frequency } \\
\hline & Never in a year & 53 & 17.5 \\
\hline & $1-5$ times a year & 130 & 42.9 \\
\hline & $6-10$ times a year & 51 & 16.8 \\
\hline & Once a month & 26 & 8.6 \\
\hline & Several times a month & 43 & 14.2 \\
\hline \multicolumn{4}{|c|}{ Product preference } \\
\hline & Electronics \& & & \\
\hline & Software & 218 & 46.1 \\
\hline & Clothes & 72 & 15.2 \\
\hline & Health care & 21 & 4.4 \\
\hline & Sports & 27 & 5.7 \\
\hline & Vehicles & 3 & 0.6 \\
\hline & Food & 79 & 16.7 \\
\hline & Cosmetic products & 33 & 7 \\
\hline & Other product & 20 & 4.2 \\
\hline \multicolumn{4}{|c|}{ Money spending (RMB) } \\
\hline & $0-100$ & 52 & 17.2 \\
\hline & $101-200$ & 33 & 10.9 \\
\hline & $201-500$ & 73 & 24.1 \\
\hline & $501-1000$ & 57 & 18.8 \\
\hline & More 1000 & 88 & 29 \\
\hline
\end{tabular}


As shown in Table 3, most of the respondents (42.9\%) made purchases one to five times per year, followed by never in a year $(17.5 \%)$, six to ten times per year $(16.8 \%)$, several times per month $(14.2 \%)$, and the rest were one time per month (8.6\%). Moreover, the respondents actively spent their money during online shopping. The respondents (29\%) stated that they had spent more $1000 \mathrm{RMB}$ in the online market, while $24.1 \%$ of the respondents had spent more than 201-500 RMB. The rest (18.8 \%) paid 501-1000 RMB, $10.9 \%$ of the espondents spent 101-200 RMB, and only $17.2 \%$ of the respondents spent less than $100 \mathrm{RMB}$.

\section{ANALYSIS AND FINDINGS}

\section{Reliability and Validity Tests}

After the collection of the questionnaires, the results of the statistical software SPSS 23 and SmartPLS 3.0 were used to analyze the data. SPSS 23 tool helped with the data analysis, while Partial Least Squares (PLS) analysis was used to test the research hypotheses. The SmartPLS algorithm allowed examining simultaneously the structural components of the model and measuring the contribution to the composite score of the latent variable. (Chin et al., 2003; Henseler et al., 2009).

The reliability of the conceptual model was measured by Cronbach's alpha (see Table 4). Cronbach's alpha reflected the constructs stability and consistent. The construct $\alpha$ value should exceed 0.7 to show good reliability level (Cho \& Kim, 2014). Critical Ratio (CR) and average variance extracted (AVE) were used to evaluate convergent validity. It is acceptable if CR exceeds 0.7 and AVE is greater than 0.5 (Chin, 1998; Hair et al., 2006). Table 4 indicates that CR constructs' values are above 0.7, and AVE values are greater than 0.5 .

Furthermore, to examine the conceptual model, it was also necessary to measure discriminant validity. The discriminant validity showed how special or well defined is a measure, calculated by the cross loading of all indicator items in connection with their respective latent variables.

TABLE 4

TEST RESULTS OF CONVERGENT VALIDITY AND RELIABILITY

\begin{tabular}{lrrrrrrrr}
\hline Latent Variables & Cronbach's $\alpha$ & CR & AVE & CE & PRIV & PROD & FIN & PI \\
\hline CE & 0.719 & 0.854 & 0.661 & $\mathbf{0 . 8 1 3}$ & & & & \\
PRIV & 0.733 & 0.832 & 0.556 & -0.029 & $\mathbf{0 . 7 4 5}$ & & & \\
PROD & 0.785 & 0.856 & 0.544 & -0.131 & 0.401 & $\mathbf{0 . 7 3 7}$ & & \\
FIN & 0.781 & 0.850 & 0.533 & -0.150 & 0.416 & 0.532 & $\mathbf{0 . 7 3 0}$ & \\
PI & 0.85 & 0.894 & 0.630 & 0.329 & -0.020 & -0.030 & -0.066 & $\mathbf{0 . 7 9 4}$ \\
\hline
\end{tabular}

Note: 1. CE: online customer experience, 2. PRIV: privacy risk, 3. PROD: product risk, 4. FIN: financial risk, 5. PI: online purchase intention

Result showed that Cronbach's alpha for online customer experience was 0.719 , for privacy risk was 0.733 , for product risk was 0.785 , for financial risk was 0.781 , for online purchase intention was 0.85 and the Alpha Cronbach of the questionnaire was 0.778. The results of the Cronbach's alpha are presented in Table 4, verifying the good reliability of the measurement model. To demonstrate discriminant validity, the square root of each construct's AVE should be higher than the correlation of the construct with other latent variables (Fornell \& Larcker, 1981). The results are also presented in Table 4, showed the good discriminant validity of the measurement model.

\section{Hypotheses Tests}

The hypothesized relationships between constructs were tested. The significance of each path was assessed based on a bootstrap resampling procedure with 500 resamples. The analysis results are 
presented in Table 5. Product risk had a negative effect on online purchase intention. Therefore, hypothesis 1 was supported. Financial risk and privacy were found to have no significant relationships with purchase intention. Thus, $\mathrm{H} 2$ and $\mathrm{H} 3$ were not supported.

Online customer experience was firmly associated with product risk. Customer experience was negatively related to product risk. Therefore, $\mathrm{H} 4$ was supported. Online customer experience had a strong negative effect on financial risk and privacy risk. Hence, H5 and H6 were supported. Finally, online customer experience was positively related to online purchase intention. Thus, $\mathrm{H} 7$ was supported.

FIGURE 2

THE STRUCTURAL MODEL TESTS

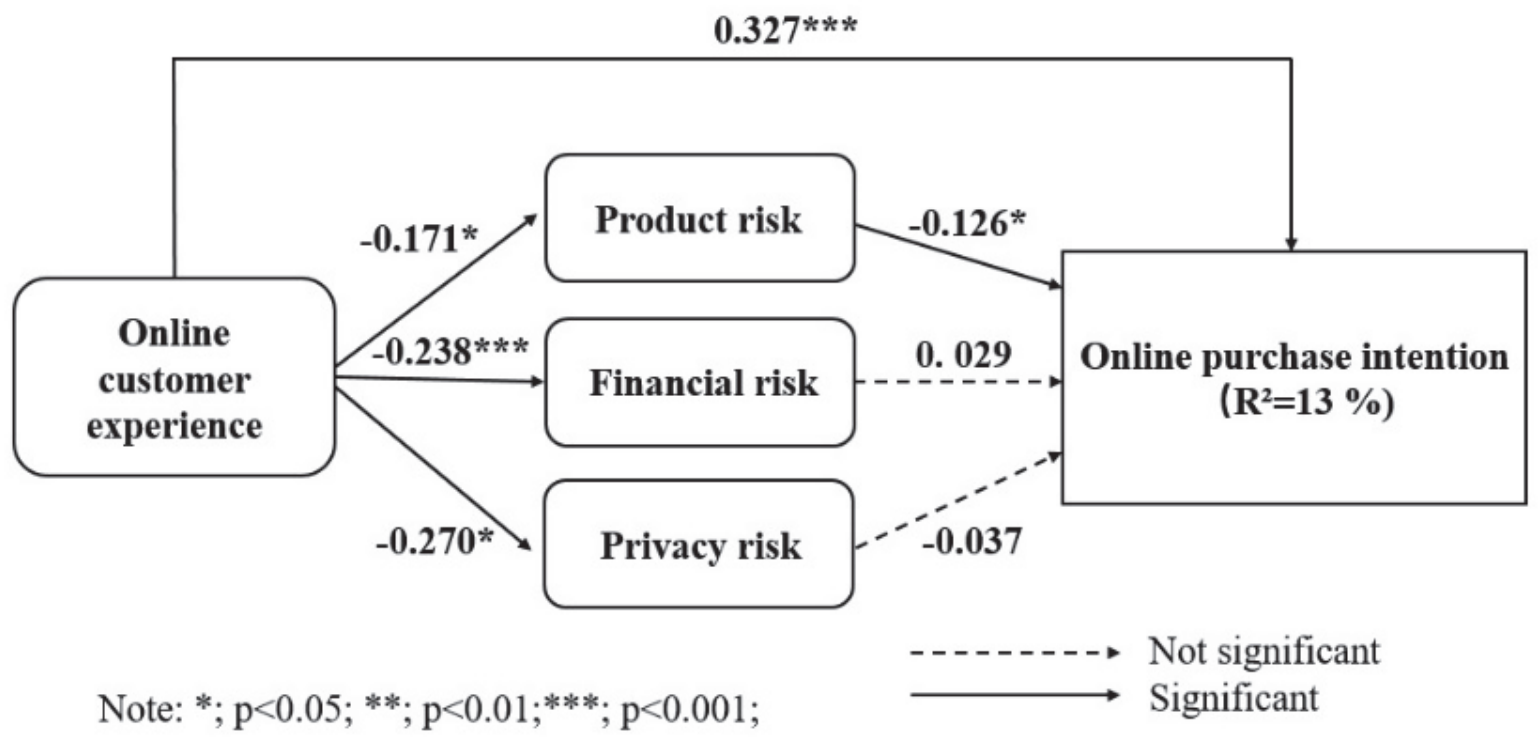

TABLE 5

RESULTS OF PROPOSED MODEL

\begin{tabular}{lccl}
\hline Paths & Path coefficients & Hypotheses & Test results \\
\hline PROD $\rightarrow$ PI & $-0.126^{*}$ & H1 & Supported \\
FIN $\rightarrow$ PI & 0.029 & H2 & Not Supported \\
PRIV $\rightarrow$ PI & -0.037 & H3 & Not Supported \\
CE $\rightarrow$ PROD & $-0.171^{*}$ & H4 & Supported \\
CE $\rightarrow$ FIN & $-0.238^{* * *}$ & H5 & Supported \\
CE $\rightarrow$ PRIV & $-0.27^{*}$ & H6 & Supported \\
FIN $\rightarrow$ PI & $0.327^{* * *}$ & H7 & Supported \\
\hline
\end{tabular}

Note: $* * * p<.001, * * p<.01, * p<0.05$, n.s.: not significant

\section{DISCUSSION AND CONCLUSION}

This study investigates how online customer experience and perceived risk affect online purchase intentions, and examines the influence of online customer experience on perceived risk. Theoretical research model consists of perceived risk dimensions (product, financial, privacy), online customer experience and purchase intentions. The measurement model analysis showed that the validity and reliability of all constructs fulfilled the requirements. Based on the findings of the research, the 
connection between purchase intentions and online shopping experience had the strongest relationship. The high impact of customer experience on online purchase intentions was proved by the previous studies (Zhou et al., 2007; Kuhlmeier \& Knight, 2005). The results also indicated that privacy and financial risk had no significant effect on purchase intentions. The results are consistent with the previous studies (Dai et al., 2014; Beneke et al., 2012). At the same time, product risk had a negative impact on purchase intentions. The findings of product risk are aligned with the previous research that product risk has a negative impact on online purchase intentions (Kamalul Affirin et al., 2018). Based on the model tests, online customer experience had a significant and negative impact on perceived risk. This result is in line with previous research findings (Kuhlmeier \& Knight, 2005; Doolin et al., 2005).

The findings of the present study have crucial insights and managerial implications. It provides marketers and retailers with important strategies in the online shopping environment. According to the demographic analysis, the majority of respondents were Chinese students with a Master's degree. They had considerable Internet experience and preferred to buy electronics online. Marketers can conclude that respondents were not sensitive to privacy and financial risks.

Meanwhile, it is interesting to note that privacy and financial risks do not significantly affect customer purchase intentions in e-commerce. Online experience positively influences online purchase intentions and reduces the negative effect on purchase intentions. Nevertheless, product risk still has a strong unfavorable impact on online purchase intention. Online retailers should focus their attention and effort on this group of consumers to reduce their product risk perception and modify online purchase preferences. For this purpose, retailers minimize the perceived product risks, particularly in their efforts to provide more information about products. Nowadays the limited number of products are still represented on the Internet, online consumers cannot obtain all the necessary goods, which they could find at the real market. Reliable information can ensure consumers about product quality and availability.

By focusing on this target group, online retailers may attract more customers to visit online stores and ultimately increase sales volumes. Next, to increase online purchasing, online stores should make the buying process online much simpler and more convenient. The good design and clear interface could motivate consumers to purchase online, thereby increasing their online experience.

The present study findings provide opportunities for future research studies. First, this study only examines three dimensions of perceived risk and online experience, eliminates the generalization of the results. Future studies should take into account a wider range of factors in the context of online purchase intentions. Second, future research studies could examine the gender roles in online purchase intentions. Nowadays, little is known about the moderating role of gender in the relationship between online experience, perceived risk, and purchase intention. Third, data collection was only taken from Jing Dong, one of the largest e-commerce sites in China. Although Jing Dong is very popular among young people, there are different online platforms in China for data collection. Thus, future research should include other shopping sites to improve data validity.

\section{ACKNOWLEGEMENT}

Thank you my supervisor Prof. Jing Zhang for the continuous support and guidance.

\section{REFERENCES}

Akbariyeh, H., Mirabi, D. V., \& Tahmasebifard, H. (2015). A study of factors affecting on customers purchase intention: case study: The agencies of bono brand tile in Tehran. Journal of

Multidisciplinary Engineering Science and Technology, 2(1), 267-273.

Almousa, M. (2011). Perceived risk in apparel online shopping: a multi-dimensional perspective. Canada Social Science, 7(2), 23-31.

Alreck, P., \& Settle, R, B. (2002). Gender effects on internet, catalogue and store shopping. Journal of Database Management \& Customer Strategy Management, 9(2), 150-162. https://doi.org/10.1057/palgrave.jdm.3240071 
Ashoer, M., \& Said, S. (2016, April). The impact of perceived risk on consumer purchase intention in Indonesia; A social commerce study. International Conference on Accounting, Management, Economics and Social Sciences, Millenium Hotel, Jakarta, Indonesia.

Beneke, J., Greene, A., Lok, I., \& Mallett, K. (2012). The influence of perceived risk on purchase intent the case of premium grocery private label brands in South Africa. Journal of Product \& Brand Management, 21(1), 4-14. http://doi:10.1108/10610421211203060

Bhatnagar, A., \& Ghose, S. (2004). Segmenting consumers based on the benefits and risks of internet shopping. Journal of Business Research, 57(12), 1352-1360. https://doi.org/10.1016/s01482963(03)00067-5

Bhatnagar, A., Misra, S., \& Rao, H. R. (2000). On risk, convenience, and internet shopping behavior. Communications of the ACM, 43(11), 98-114. https://doi.org/ 10.1145/353360.353371

Bourlakis, M., Papagiannidis, S., \& Fox, H. (2008). E-consumer behaviour: Past, present and future trajectories of an evolving retail revolution. International Journal of E-Business Research, 4(3), 64-76. https://doi.org/10.4018/jebr.2008070104

Bruseke, L. (2016, December). The influence of privacy perceptions on online shopping behavior - a comparison between millennials and baby boomers. 7th IBA Bachelor Thesis Conference, Enschede, The Netherlands.

Chang, H. H., \& Wang, H. (2011). The moderating effect of customer perceived value on online shopping behaviour. Online Information Review, 35(3),333-359. https://doi:10.1108/14684521111151414

Chang, H. H., \& Wang, H. W. (2011). The moderating effect of customer perceived value on online shopping behaviour. Online Information Review, 35(3), 333-359.

https://doi: $10.1108=14684521111151414$

Chapell, A. (2005). Eye on privacy. Target Marketing, 28(10), 27.

Chen, Y. H., \& S. Barnes, S. (2007). Initial trust and online buyer behaviour. Industrial Management \& Data Systems, 107 (1), 21-36. https://doi:10.1108=02635570710719034

Chin, W.W. (1998). The partial least squares approach for structural equation modeling. In GA Marcoulides (ed.), Modern Methods for Business Research.

Chin, W.W., Marcolin, B.L., \& Newsted, P.R. (2003). A partial least squares latent variable modeling approach for measuring interaction effects: Results from a Monte Ccarlo simulation study and an electronic-mail emotion/adoption study. Information Systems Research, 14(2), 189-217. http://dx.doi.org/10.1287/isre.14.2.189.16018

Cho, E., \& Kim, S. (2014). Cronbach's coefficient alpha. Organizational Research Methods, 18(2), 207230. https://doi.org/10.1177/1094428114555994

Close, A.G., \& Kukar-Kinney, M. (2010). Beyond buying: Motivations behind consumers' online shopping cart use. Journal of Business Research, 63(9-10), 986-992. https://doi.org/10.1016/j.jbusres.2009.01.02

Dai, B., Forsythe, S., \& Kwon, S. W. (2014). The impact of online shopping experience on risk perceptions and online purchase intentions: Does product category matter? Journal of Electronic Commerce Research, 15(1), 13-24.

Doolin, B., Dillon, S., Thompson, F., \& Corner, J. L. (2005). Perceived Risk, the Internet Shopping Experience and Online Purchasing Behavior. Journal of Global Information Management, 13(2), 66-88. https://doi:10.4018/jgim.2005040104

Drennan, J., Sullivan, G., \& Previte, J. (2006). Privacy, risk perception and expert online behavior: an exploratory study of household end users. Journal of Organizational and End User Computing, 18 (1), 1-22. https://doi.org/10.4018/joeuc.2006010101

Durmus, B., Ulusu, Y., \& Akgun, S. (2017). The effect of perceived risk on online shopping through Trust and WOM. International Journal of Management and Applied Science, 3(9), 103-108.

Festervand, T. A., Snyder, D.R., \& Tsalikis, J. D. (1986). Influence of catalogue vs. store shopping and prior satisfaction on perceived risk. Academy of Marketing Science, 14(4), 28-36. https://doi:10.1007/bf02721813 
Fornell, C., \& Larcker, D. F. (1981). Structural equation models with unobservable variables and measurement error: Algebra and statistics. Journal of Marketing Research, 18(3), 382. https://doi.org/10.2307/3150980

Forsythe, S. M., \& Shi, B. (2003). Consumer patronage and perceptions in Internet shopping. Journal of Business Research, 56 (11), 867-875. https://doi:10.1016/s0148-2963(01)00273-9

Forsythe, S., Liu, C., Shannon, D., \& Gardner, L. C. (2006). Development of a scale to measure the perceived benefits and risks of online shopping. Journal of Interactive Marketing, 20(2), 55-75. https://doi.org/10.1002/dir.20061

Gan, C., \& Wang, W. (2017). The influence of perceived value on purchase intention in social commerce context. Internet Research, 27(4), 772-785. https://doi:10.1108/intr-06-2016-0164

Garbarino, E., \& Strahilevitz, M. (2004). Gender differences in the perceived risk of buying online and the effects of receiving a site recommendation. Journal of Business Research, 57(7), 768-775. https://doi.org/10.1016/s0148-2963(02)00363-6

Gerber, C., Ward, S., \& Goedhals-Gerber, L. (2014). The impact of perceived risk on on-line purchase behaviour. Risk Governance and Control: Financial Markets \& Institutions, 4(4), 99-106. https://doi:10.22495/rgcv4i4c1 art4

Grewal, D., Levy, M., \& Kumar, V. (2009) Customer experience management in retailing: An organizing framework. Journal of Retailing, 85 (1), 1-14. https://doi.org/10.1016/j.jretai.2009.01.001

Gurung, A., \& Raja, M. (2016). Online privacy and security concerns of consumers. Information and Computer Security, 24 (4), 348-371. https://doi.org/10.1108/ics-05-2015-0020

Hair, J. F. (2006). Multivariate data analysis (6th ed.). Upper Saddle River, N.J.: Pearson Prentice Hall.

Henseler, J., Ringle, C., \& Sinkovics, R. (2009). The use of partial least squares path modeling in international marketing. Advance in International Marketing, 20, 277-319. http://dx.doi.org/10.1108/S1474-7979(2009)0000020014

Holloway, B. B., Wang, S., \& Parish, J. T. (2005). The role of cumulative online purchasing experience in service recovery management. Journal Of Interactive Marketing, 19(3), 54-66. . https://doi:10.1002/dir.20043

Hong, W., \& Thong, J. Y. L. (2013). Internet privacy concerns: An integrated conceptualization and four empirical studies. MIS Quarterly, 37 (1), 275-298. https://doi.org/10.25300/misq/2013/37.1.12

Horton, R. L. (1984). The structure of perceived risk: Some further progress. Journal of the Academy of Marketing Science, 4 (4), 694-706. https://doi.org/10.1007/bf02729830

Internet World Stats (2019). Internet usage in Asia. Retrieved March 3, 2019, from https://www.internetworldstats.com/stats $3 . h t m$

Jiuan Tan, S. (1999). Strategies for reducing consumers' risk aversion in Internet shopping. J. Consumer Marketing, 16(2), 163-180. https://doi.org/10.1108/07363769910260515

Johnston, R., \& Kong, X. (2011). The customer experience: A road-map for improvement. Managing Service Quality: An International Journal, 21(1), 5-24. https://doi:10.1108/09604521111100225

Kamalul Affirin, S., Mohan, T., \& Goh, Y. (2018). Influence of consumers' perceived risk on consumers' online purchase intention. Journal of Research in Interactive Marketing, 12(3), 309-327. https://doi.org/10.1108/jrim-11-2017-0100

Kim, D. J., Ferrin, D. L., \& Rao, H. R. (2008). A trust-based consumer decision-making model in electronic commerce: The role of trust, perceived risk, and their antecedents. Decision Support Systems, 44(2), 544-564. http://doi.org/10.1016/j.dss.2007.07.001

Kim, J., Jin, B., \& Swinney, J. L. (2009). The role of etail quality, e-satisfaction and e-trust in online loyalty development process. Journal of Retailing and Consumer Services, 16(4), 239-247. https://doi:10.1016/j.jretconser.2008.11.019

Kuhlmeier, D., \& Knight, G. (2005). Antecedents to internet-based purchasing: A multinational study. International Marketing Review, 22(4), 460-473. https:// 10.1108/02651330510608460

Liang, T., \& Huang, J. (1998). An empirical study on consumer acceptance of products in electronic markets: A transaction cost model. Decision Support Systems, 24(1), 29-43. https://doi:10.1016/s0167-9236(98)00061-x 
Ling, K. C., Chai, L. K., \& Piew, T. H. (2010). The effects of shopping orientations, online trust and prior online purchase experience toward customers' online purchase intention. International Business Research, 3(3), 63-76.

Mekovec, R., \& Hutinski, Ž. (2012, May). The role of perceived privacy and perceived security in online market. 2012 Proceedings of the 35th International Convention MIPRO, Opatija, Croatia, 18831888.

Meskaran, F., Ismail, Z., \& Shanmugam, B. (2013). Online purchase intention: effects of trust and security perception. Australian Journal of Basic and Applied Sciences, 7(6), 307-315.

Michaud-Trevinal, A., \& Stender, T. (2012, May). Online shopping experiences: A qualitative research. Conference: Academy of Marketing Science Annual, New-Orleans, 2012.

Miles, M. B., \& Huberman, A. M. (1994). Qualitative data analysis: An expanded sourcebook (2nd ed.). Thousand Oaks, CA, US: Sage Publications, Inc.

National Bureau of Statistics of China (2019). National economic performance maintained within an appropriate range in 2018 with main development goals achieved. Retrieved March 4, 2019, http://www.stats.gov.cn/english/PressRelease/201901/t20190121_1645832.html

Nieves-Rodriguez, E., Perez-Rivera, M. M., Longobardi, T., \& Davis-Pellot, J. A. (2017). Culture and gender's role in apparel purchasing patterns. Journal of Fashion Marketing and Management: An International Journal, 21(1), 16-32. https://doi:10.1108/jfmm-04-2016-0032

Pavlou, P. A. (2003). Consumer acceptance of electronic commerce: Integrating trust and risk with the technology acceptance model. International Journal of Electronic Commerce, 7(3), 197-226.

Peter, J. P., \& Tarpey, L. X. (1975). A comparative analysis of three consumer decision strategies. Journal of Consumer Reasearch, 2 (1), 29-37. https://doi.org/10.1086/208613

Reuters (2019). JD.com Inc overview. Retrieved March 5, 2019, from https://www.reuters.com/finance/stocks/company-profile/JD.OQ

Rose, S., Clark, M., Samouel, P., \& Hair, N. (2012). Online customer experience in e-retailing: An empirical model of antecedents and outcomes. Journal of Retailing, 88(2), 308-322. https://doi:10.1016/j.jretai.2012.03.001

Salisbury, W. D., Pearson, R. A., Pearson, A.W. \& Miller, D.W. (2001). Perceived security and worldwide web purchase intention. Industrial Management \& Data Systems, 101(4), 165-177. https://doi.org/10.1108/02635570110390071

Seckler, V. (2000, July). Survey says web apparel buys doubled, Women Wear Daily, 180 (6), 2.

Shim, S., \& Drake, M.F. (1990). Consumer intention to utilize electronic shopping. The Fishbein behavioral intention model. Journal Of Direct Marketing, 4(2), 22-33. https://doi:10.1002/dir.4000040305

Sweeney, J. C., Soutar G. N., \& Johnson L. W. (1999). The role of perceived risk in the quality-value relationship: A study in a retail environment. Journal of Retailing, 75 (1), 77-105. https://doi.org/10.1016/s0022-4359(99)80005-0

Verhoef, P.C., Lemon, K.N., Parasuraman, A., Roggeveen, A., Tsiros, M. \& Schlesinger, L.A. (2009). Customer experience creation: Determinants, dynamics and management strategies. Journal Of Retailing, 85 (1), 31-41. https://doi:10.1016=j.jretai.2008.11.001

Zhang, L., Tan, W., Xu, Y. \& Tan, G. (2012). Dimensions of consumers "e perceived risk and their influences on online consumers"e purchasing behaviour. Communications in Information Science and Management Engineering, 2 (7), 8-14.

Zhang, L., Xu, Y., Ye, B., \& Wang, Q. (2012). Exploring differences of consumers' perceived factors in shopping online: The effects of shopping experience and gender. Lecture Notes in Electrical Engineering Advances in Electronic Engineering, Communication and Management, 1, 639-646. https:// doi:10.1007/978-3-642-27287-5_104

Zhou, L., Dai, L., \& Zhang, D. (2007). Online shopping acceptance model - a critical survey of consumer factors in online shopping. Journal Of Electronic Commerce Research, 8(1), 41-62. 


\section{APPENDIX A}

\section{MEASUREMENT ITEMS}

\begin{tabular}{ll}
\hline Dimension & \multicolumn{1}{c}{ Items } \\
\hline Privacy risk & 1. I am concerned that somebody can find my private information on the Internet. \\
2. JD.com may give my personal information (mobile number, email) to other companies. \\
3. I may be contacted by other online companies without my permission after the \\
completion of online transaction in JD.com. \\
4. JD.com may follow my online shopping habits and history purchases \\
Product risk \\
1. The products' quality is difficult for me to judge adequately on JD.com. \\
2. The actual quality of the similar products is hard to compare. \\
3. Goods ordered in JD.com may not personally satisfy me. \\
4. The quality of the products in JD.com is different from its description. \\
5. It's difficult for me to touch and examine product from JD.com \\
Financial \\
risk \\
1. My bank card number may not be secure during purchasing in JD.com. \\
2. Using the online payment services in JD.com may charge me an additional fee. \\
3. Online shopping in JD.com may cost more money than somewhere else \\
4. Delivery service in JD.com will cost me extra money. \\
5. The possibility that I may not receive my online purchase delivered by JD.com is high \\
1. I will use JD.com to purchase products online in the future even though it is not the \\
only way to purchase products I need. \\
2. I would consider visiting JD.com online platform if I have the need for such products \\
in next 6 months. \\
3. If I see some good product for myself, probably I will use JD.com to purchase it online \\
4. I will use JD.com for buying products, which are hard to get in the real shopping mall \\
5. I will recommend my friends to visit JD.com platform for online shopping.
\end{tabular}

